\title{
Distal Bile Duct Cancer cM0 TNM Finding v7
}

National Cancer Institute

\section{Source}

National Cancer Institute. Distal Bile Duct Cancer cMO TNM Finding v7. NCI Thesaurus.

Code C90262.

Distal bile duct cancer without evidence of distant metastasis. (from AJCC 7th Ed.) 